used fewer tablets on placebo than on the drug, and one used equal numbers in both periods. This result is statistically highly significant $(P<0.01)$. Seven patients had improved pain-free effort tolerance while on the drug; there was no difference between the two periods in the other 12 patients. This is statistically significant $(P<0.04)$.

Slowing of the resting heart rate was often noted while patients were receiving propranolol. The mean heart rate of the 19 patients on the drug was 63 ; on placebo it was 78 . There was some correlation between bradycardia and decrease in frequency of anginal attacks. Slowing of heart rate was noted in 15 patients while on propranolol; this was associated with decreased frequency of angina in 12 . No alteration in the heart rate was noted in the other four patients; only one of these (Case 12) showed a reduced frequency of attacks.

Eighteen patients were normotensive. Fall in blood-pressure while taking propranolol was recorded in only one of these. The remaining patient (Case 15) was hypertensive (B.P.200/ 100). While taking propranolol the tension dropped to $200 / 80$.

No change in blood picture or S.G.P.T. or evidence of albuminuria was found in any of the patients. Similarly, there was no change in the body weight or electrocardiogram. No patient developed evidence of cardiac failure during the trial. Apart from dizziness in one patient there were no side-effects.

\section{Discussion}

It was suggested by Black and Stephenson (1962) that specific beta-receptor blockade might be beneficial in angina pectoris, because of reduction in the oxygen requirements of cardiac muscle. This hypothesis is supported by the results of the present trial, which show, in addition to reduction in number of anginal attacks and consumption of glyceryl trinitrate tablets, improvement in pain-free effort tolerance.

There is one other report of a double-blind trial of propranolol in angina of effort (Srivastava et al., 1964) in the literature. A series of 20 patients were given propranolol $20 \mathrm{mg}$. t.i.d. for three weeks and placebo for a further three weeks. No significant difference between drug and placebo was found. It is possible that the smaller dose of propranolol used may have been subtherapeutic. In this context it is relevant that slowing of the heart rate was not observed in any patient during the trial. This suggests that effective blockade of myocardial adrenergic beta-receptors was not achieved.

Improved exercise tolerance following intravenous injection of propranolol in patients previously limited by angina has been reported recently (Hamer et al., 1964). The same authors found that beta-adrenergic blockade reduced the heart rate at all levels of exercise, but Bishop and Segel (1963) and Chamberlain and Howard (1964) have shown that the cardiac output on exercise in the erect position is maintained.

From preliminary investigation of propranolol it seems likely that intestinal absorption is incomplete and variable (S. A. Stephen, personal communication, 1964). Therefore it may be that some patients will require larger doses than those prescribed in this trial. It is proposed to restudy, using larger doses of propranolol, those patients who did not respond to $30 \mathrm{mg}$. t.i.d.

\section{Summary}

A double-blind trial of propranolol has been carried out on 19 patients suffering from angina of effort. The drug was found to be significantly better than placebo in reducing the frequency of attacks of angina pectoris and the number of glyceryl trinitrate tablets taken, and in improving pain-free effort tolerance.

I thank Dr. S. Blake, Professor T. B. Counihan, and Dr. M. Moriarty for permission to study patients under their care. I am grateful to the sister and staff of the cardiac department, to the pharmacist, Mr. L. A. Ryan, and to the laboratory staff for cooperation. My thanks are also due to Dr. S. A. Stephen and Mr. C. Clarke, of Imperial Chemical Industries Limited, Pharmaceuticals Division.

\section{REFERENCES}

Alleyne, G. A. O., Dickinson, C. J., Dornhorst, A. C., Fulton, R. M., Green, K. G., Hill, I. D., Hurst, P., Laurence, D. R., Pilkington, T., Prichard, B. N. C., Robinson, B., and Rosenheim, M. L. (1963). Brit. med. $\dot{f}$., 2, 1226.

Bishop, J. M., and Segel, N. (1963). f. Physiol. (Lond.), 169, 112 P.

Black, J. W., Crowther, A. F., Shanks, R. G., Smith, L. H. and Dornhorst, A. C. (1964). Lancet, 1, 1080.

Dornhorst, A. C. (1964); Lancet, 1, 1080.

Chamberlain, D. A., and Howard, J. (1964). Brit. Heart f., 26, 213.

Hamer, J., Grandjean, T., Melendez, L., and Sowton, G. E. (1964). Brit. med. $7 ., 2,720$.

Paget, G. E. (1963). Ibid., 2, 1266.

Srivastava, S. C., Dewar, H. A., and Newell, D. J. (1964). Ibid., 2, 724.

\title{
Clinical Evaluation of Human Amnion Tissue Culture
}

\author{
E. G. JONAS,* M.B., B.S., F.R.C.S., M.R.c.o.g. ; ANNE E. CAUNT, $†$ B.SC., DIP.BACT.
}

Brit. med. F., 1965, 1, 898-901

Since Zitcer, Fogh, and Dunnebacke (1955) described the use of human amnion culture for growing poliomyelitis virus, this method has become widely used for growing an increasing range of viruses. Most virologists have experienced some failure of amnion to grow, and Duncan and Bell (1961) suggested that the state of viability of the amnion at the time of delivery was more decisive than technical details of its subsequent processing. The experience of this laboratory supports that view, as it proved possible to grow in culture $90 \%$ of amnions by discarding obviously damaged-that is, opaque or meconium-stained-membranes.

* Consultant Obstetrician and Gynaecologist, Uxbridge Group of Hospitals; formerly Senior Registrar, Liverpool
Lecturer in Bacteriology, University of Liverpool.
As amnion is a foetal tissue, and taking Duncan and Bell's suggestion to its logical conclusion, it is possible that the behaviour of amnion in tissue culture mirrors foetal growth and development. To test this hypothesis, and in the hope of finding clear predictors of successful culture of this tissue, results of 314 consecutive amnion culture attempts were correlated with selected clinical data.

\section{Laboratory Materials and Methods}

Collection of Placentae.-Only sterile normal saline was used for swabbing patients in the course of vaginal deliveries. Whole placentae were collected in dry, sterile jars. Those from caesarean sections were usually transferred to the laboratory 
within one hour of delivery, but the interval after vaginal delivery was less constant, varying from half an hour to eight hours. A few placentae were obtained in the later afternoon: their amnion was stripped, washed, stored overnight at room temperature, and processed the next morning (Duncan and Bell, 1961).

Tissue-culture Procedure.-The amnion was stripped from the placenta and processed as described by Zitcer et al. (1955), with the following modifications: a fragment of tissue was cultured in nutrient broth before trypsinization, and cultures showing bacterial growth after 24 hours' incubation were excluded from the series. Accepted specimens were trypsinized at $34^{\circ} \mathrm{C}$. rather than at $37^{\circ} \mathrm{C}$., to avoid cell damage (Lahelle, 1956). The first 20 minutes' trypsinized extract was discarded and was followed by two extractions of one hour each with gentle stirring. These specimens were pooled and the unwashed centrifuged sediment was resuspended in sufficient growth medium to give a suspension of 4 to $5 \times 10^{5}$ cells per ml. The medium was changed 48 hours after the cultures were set up, and then at intervals of five to seven days. Cultures were not recorded as failures until after at least two changes of medium, since occasionally the initiation of growth was slow, although satisfactory monolayers formed eventually.

The growth medium used for the first 260 amnions was $10 \%$ horse serum, $10 \%$ tryptic digest broth, and $0.0292 \%$ glutamine in Hanks's saline ; but for the remaining 54 amnions Eagle's medium with $10 \%$ horse serum was used. 100 units of penicillin and $100 \mu \mathrm{g}$. of streptomycin per ml. were added regularly, and 50 units of nystatin per ml. occasionally. The horse serum used had been found in earlier experiments (Caunt, unpublished) to equal good human serum, and to be much less variable than different batches of the latter for the growth of amnion cells. Earlier experiments had shown that there was no advantage to be gained from addition of lactalbumin hydrolysate or chick-embryo extract to the tryptic digest broth and glutamine. When Eagle's medium became readily available to us, 10 amnions were set up in parallel in this medium and in the tryptic digest broth and glutamine mixture: no difference in the resulting tissue cultures was noted, although in one case confluent sheets were obtained more rapidly in Eagle's medium.

Assessment of Tissue Cultures.-Amnion cultures recorded as "growing" formed confluent sheets or very large islands of cells, usually within nine days. The yield varied from 5 to $250 \times 10^{8}$ or more cells. Those recorded as " not growing" either did not yield any whole cells or, if cells were obtained, they did not divide or did so only once or twice to give islets of four to eight cells. It is possible that this last group, which grew a little, should be considered separately from those that did not yield any viable cells, but from the practical point of view none of these cultures was usable.

\section{Results}

Meconium-stained Membranes.-The previous observation that membranes stained with meconium fail to yield viable cells was confirmed.

Interval Between Delivery and Processing (Table I).-The 159 amnions referred to in Table I were from "normal"

TaBle I.-Effect of Interval Between Delivery and Use on Growth

\begin{tabular}{|c|c|c|c|c|c|c|c|c|c|}
\hline \multirow{3}{*}{$\begin{array}{l}\text { Interval } \\
\text { (hours) }\end{array}$} & \multicolumn{3}{|c|}{ Total } & \multicolumn{3}{|c|}{ Vaginal } & \multicolumn{3}{|c|}{ Caesarean Section } \\
\hline & \multirow{2}{*}{$\begin{array}{l}\text { No. } \\
\text { Examined }\end{array}$} & \multicolumn{2}{|c|}{ Growing } & \multirow{2}{*}{$\begin{array}{l}\text { No. } \\
\text { Examined }\end{array}$} & \multicolumn{2}{|c|}{ Growing } & \multirow{2}{*}{$\begin{array}{c}\text { No. } \\
\text { Examined }\end{array}$} & \multicolumn{2}{|c|}{ Growing } \\
\hline & & No. & $\%$ & & No. & $\%$ & & No. & $\%$ \\
\hline $\begin{array}{l}<1 \\
1-3 \\
>3\end{array}$ & $\begin{array}{l}50 \\
68 \\
41\end{array}$ & $\begin{array}{l}31 \\
35 \\
19\end{array}$ & $\begin{array}{l}62 \\
51.4 \\
46.3\end{array}$ & $\begin{array}{l}16 \\
45 \\
34\end{array}$ & $\begin{array}{r}9 \\
21 \\
15\end{array}$ & $\begin{array}{l}56 \cdot 2 \\
46.7 \\
44.1\end{array}$ & $\begin{array}{r}34 \\
23 \\
7\end{array}$ & $\begin{array}{r}22 \\
14 \\
4\end{array}$ & $\begin{array}{l}64.7 \\
60.9 \\
57.1\end{array}$ \\
\hline
\end{tabular}

women. By definition, these had no associated complication such as pregnancy toxaemia, and produced a live baby at term. There seems to be a slight fall in growth potential as the interval between delivery and processing lengthens, but these differences are not significant when examined by the Chisquare test $(P>0.5)$. The differences are also not significant when the totals for each group are subdivided according to the method of delivery, confirming the observations of Ferguson and Tobin (1958) and of Duncan and Bell (1961).

Length of Labour (Table II).-Results of 115 cultures from " normal" women (as defined above) delivered vaginally were grouped into "under 12 hours" and " 12 hours and over," with rates of success of $40 / 78(51.3 \%)$ and $15 / 37(40.5 \%)$ respectively, a difference statistically not significant (difference $10.8 \%$; standard error (S.E.) of difference 9.86).

TABLE II.-Effect of Length of Labour on Growth Potential of Amnion

\begin{tabular}{|c|c|c|c|c|c|}
\hline ength of Labour (hours): & $<6$ & 6- & $12-$ & $18-$ & $24+$ \\
\hline d $\quad$.. & $18 \stackrel{31}{(58 \%)}$ & $22 \begin{array}{c}47 \\
247 \%)\end{array}$ & $7 \stackrel{20}{75 \%})$ & $4 \stackrel{9}{4} \%)$ & $4 \stackrel{8}{8}$ \\
\hline
\end{tabular}

Method of Delivery (Table III).-Successful cultures were obtained from $72 \%$ of all women delivered by elective caesarean section, compared with $51.5 \%$ of all those who came to vaginal delivery. Considering only " normal" women (as defined earlier), the figures were $69.8 \%$ and $48.7 \%$ respectively. The difference in the percentages is considerably more than twice the standard error in both instances (S.E. of the difference for all cases is 5.5, for " normal " women 6.8), and therefore it is statistically significant. However, comparison between caesarean section undertaken in labour and vaginal delivery does not show any difference, but the numbers involved are too small for analysis.

TABLB III.-Effect of Method of Delivery on Growth Potential of Amnion

\begin{tabular}{|c|c|c|c|c|c|c|c|c|c|}
\hline & & & & \multicolumn{3}{|c|}{ Total } & \multicolumn{3}{|c|}{ Normal* } \\
\hline & & & & \multirow{2}{*}{$\begin{array}{l}\text { No. } \\
\text { Examined }\end{array}$} & \multicolumn{2}{|c|}{ Growing } & \multirow{2}{*}{$\begin{array}{c}\text { No. } \\
\text { Examined }\end{array}$} & \multicolumn{2}{|c|}{ Growing } \\
\hline & & & & & No. & $\%$ & & No. & $\%$ \\
\hline \multicolumn{4}{|c|}{$\begin{array}{l}\text { Vaginal delivery } \\
\text { Elective caesarean section }\end{array}$.. } & $\begin{array}{r}171 \\
125 \\
18\end{array}$ & $\begin{array}{r}88 \\
90 \\
9\end{array}$ & $\begin{array}{l}51 \cdot 5 \\
72 \cdot 0 \\
50 \cdot 0\end{array}$ & $\begin{array}{r}117 \\
83 \\
11\end{array}$ & $\begin{array}{r}57 \\
58 \\
5\end{array}$ & $\begin{array}{l}48 \cdot 7 \\
69 \cdot 8 \\
45 \cdot 4\end{array}$ \\
\hline Total & $\ldots$ & .. & .. & 314 & 187 & $59 \cdot 6$ & 211 & 120 & 56.9 \\
\hline
\end{tabular}

- Refers to cases where there was no associated maternal complication such as pregnancy toxaemia and where a live baby was born at term.

Maternal Complications (Table IV).-These included preeclampsia, essential hypertension, diabetes mellitus, and isoimmunization. The case material, especially in the latter two conditions, is small, so that no significant conclusions can be drawn. It can be seen, however, that amnions obtained from the six diabetic patients all produced satisfactory tissue cultures.

TABLE IV.-Effect of Maternal and Foetal Factors on Growth Potential of Amnion

\begin{tabular}{|c|c|c|c|c|c|c|c|c|c|}
\hline \multirow{3}{*}{ Class } & \multicolumn{3}{|c|}{ Total } & \multicolumn{3}{|c|}{$\begin{array}{l}\text { Vaginal } \\
\text { Delivery }\end{array}$} & \multicolumn{3}{|c|}{$\begin{array}{c}\text { Elective } \\
\text { Caesarean } \\
\text { Section }\end{array}$} \\
\hline & \multirow{2}{*}{$\begin{array}{l}\text { No. } \\
\text { Exam. }\end{array}$} & \multicolumn{2}{|c|}{ Growing } & \multirow{2}{*}{$\begin{array}{c}\text { No. } \\
\text { Exam. }\end{array}$} & \multicolumn{2}{|c|}{ Growing } & \multirow{2}{*}{$\begin{array}{l}\text { No. } \\
\text { Exam. }\end{array}$} & \multicolumn{2}{|c|}{ Growing } \\
\hline & & No. & $\%$ & & No. & $\%$ & & No. & $\%$ \\
\hline 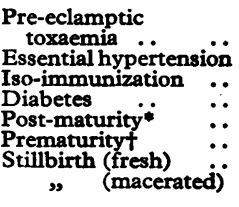 & $\begin{array}{c}34 \ddagger \\
285 \\
6 \\
6 \\
199 \\
21 \\
3 \\
3\end{array}$ & $\begin{array}{r}27 \\
13 \\
3 \\
6 \\
10 \\
16 \\
3 \\
2\end{array}$ & $\begin{array}{r}79.4 \\
46.4 \\
50.0 \\
100.0 \\
52.6 \\
76.2\end{array}$ & $\begin{array}{r}16 \\
16 \\
3 \\
1 \\
9 \\
12 \\
3 \\
3\end{array}$ & $\begin{array}{r}12 \\
6 \\
2 \\
1 \\
3 \\
9 \\
3 \\
2\end{array}$ & $\begin{array}{l}75 \cdot 0 \\
37.5 \\
. \\
33.3 \\
75.0\end{array}$ & $\begin{array}{r}14 \\
10 \\
3 \\
5 \\
8 \\
9 \\
\text { nil } \\
\text { nil }\end{array}$ & $\begin{array}{r}13 \\
6 \\
1 \\
5 \\
5 \\
7\end{array}$ & $\begin{array}{r}92.9 \\
60.0 \\
100.07 \\
62.5 \\
77.7\end{array}$ \\
\hline
\end{tabular}

* Post-maturity refers to gestations of 42 weeks and over.

t Prematurity refers to babies weighing $5 \frac{1}{2} \mathrm{lb}$. $(2,500 \mathrm{~g}$.) or less at birth

¥ Four were emergency caesarean sections.

Two were emergency caesarean sections.

I Two were emergency caesarean sections. 
Amnions from patients with pre-eclampsia showed a noticeably high culture success rate irrespective of the method of delivery. It was $75 \%$ for vaginal deliveries compared with $48.7 \%$ for "normal" vaginal births (see Table III) (difference in percentages 26.3, S.E. of difference 11.77), and $92.9 \%$ for caesarean sections compared with $69.8 \%$ for "normal" caesarean sections (difference 23.1, S.E. of difference 8.9). A success rate lower than that of corresponding "normal" women occurred in amnions from patients with essential hypertension, again irrespective of method of delivery. However, these differences are not statistically significant (S.E. is equal to or greater than the differences).

Condition of Baby (Table IV).- Tissue culture results using amnion from premature babies (birth weight $5 \frac{1}{2} \mathrm{lb}$. (2,500 g.) or less) were good, with a $76 \%$ success rate, which is $19.3 \%$ better than amnions from "normal" women (S.E. of difference 9.899). Only two tissue cultures in this group failed to grow: in one there was severe meconium-staining, while the other conceptus was a macerated stillbirth. Amnion from “post-mature" babies, arbitrarily defined as of 42 weeks' gestation or longer, gave a low success rate $(52.6 \%)$, especially after vaginal delivery $(33.3 \%)$. Amnion derived from two out of three macerated stillbirths and from each of three fresh stillbirths grew well in tissue culture.

Length of Gestation.-Both prematurity and post-maturity are concepts which are difficult to define. To amplify the findings described in the previous paragraph the results of tissue cultures from "normal" women and from otherwise uncomplicated instances of prematurity and post-maturity were analysed with respect to length of gestation, birth weight, and method of delivery (Table V). It is seen that the culture success rate falls progressively with increasing length of gestation, the fall being statistically significant $(P<0.01$ for " total " cases in Table V, examined by the Chi-square test). The success rate in almost every category is lower for amnions obtained from vaginal deliveries than for those from caesarean sections. This shows our observation (see Table III) of the effect of labour on growth potential to be a valid one, and independent of length of gestation. Birth weight has less influence on the growth potential of amnion, presumably because it does not correlate exactly with length of gestation, as is shown within any given week of gestation in Table V.

\section{Discussion}

The following points emerging from this study deserve further consideration.

\section{Effect of Length of Gestation and Labour on Amnion-culture Response}

The finding that growth of amnion in tissue culture progressively declines with increasing length of gestation (see Table V) is not unexpected. It follows logically on the well-entrenched idea of an " ageing," functionally failing placenta, to which the amnion is morphologically and anatomically related.

The occurrence of labour, whether ending in vaginal delivery or caesarean section, also appears to result in a reduced growth potential of amnion (see Table III), but this must be considered in conjunction with our observation that length of labour, at any rate in "normal" women, does not affect tissue-culture results significantly (see Table II). It seems reasonable to postulate that the occurrence of labour per se and a tendency to reduced growth potential of amnion in tissue culture in the final weeks of uncomplicated pregnancy are concurrent, not cause and effect, and it may well turn out to be an authentic biological phenomenon heralding onset of labour.

\section{Relation of Intrauterine Death to Amnion-culture Response}

This topic cannot be fully appraised because of paucity of material and the fact that three of the five amnions which grew in culture came from cases of intrauterine death associated with pre-eclampsia (see below). The theory that human amnion is nourished via the amniotic fluid (Bourne, 1962a), the formation and circulation of which is generally held to depend on survival of the conceptus, is hereby weakened. Moreover, the behaviour of amnion in tissue culture cannot be taken as an index of foetal growth and development, as was postulated at the outset of this study.

\section{Effect of Pregnancy Toxaemia on Amnion-culture Response}

In this admittedly small series of cases the presence of essential hypertension had little effect on amnion growth potential, while pre-eclampsia appeared to enhance it. This does not accord with the implications of Bourne's (1962b) observation on amnion epithelial-cell necrosis in pre-eclampsia.

The possibility that increased growth potential of amnion derived from women with pre-eclampsia was due to a higher incidence of caesarean section was examined earlier (see Table IV) and considered unlikely. A link with earlier delivery is not upheld on analysis with respect to weeks of gestation: only three women were delivered on or before week 36,15 during 37 and 38 weeks, 11 during 39 and 40 weeks, and four during or after the 41 st week (in one patient the maturity was unknown).

The figures for pre-eclamptic women at 37-38 weeks' gestation are given in Table VI and compared with those for "normal " patients at that maturity. When examined in this way, the groups become very small but the trend observed in the total figures is also apparent in the component groups. The difference in the percentage success rate in the "total" line in Table VI is not quite twice the S.E., but it does suggest that it is real.

TABle V.-Effect of Maturity and Birth Weight on Amnion Growth Potential

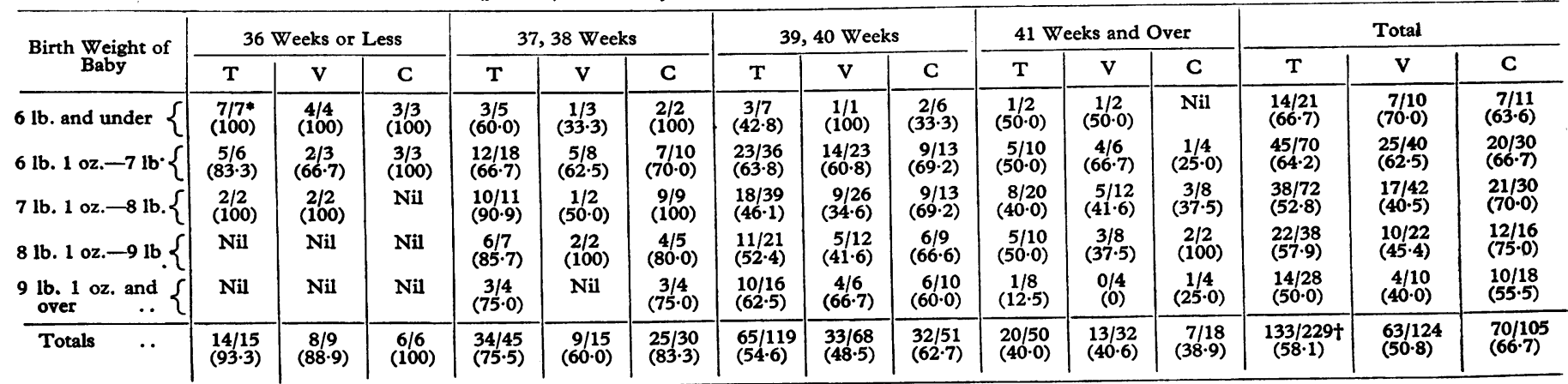

$\mathrm{T}=$ Total. $\mathrm{V}=$ Number by vaginal delivery. $\mathrm{C}=$ Number by caesarean section.

"Fractions indicate number growing/number examined. Percentages are given in parentheses. deliveries where the maturity was doubtful are excluded. 
The statistical methods we have used are extremely simple, and in most instances we have attempted to compare groups showing a single difference. While this approach could lead to oversimplification or distortion of results, an alternative method (Birch, 1964) allows more than one factor to be considered at a time, and the results obtained are substantially the same as our own.

\section{TablB VI.-Effect of Pre-eclamptic Toxaemia on Tissue Culture Response of Amnion}

\begin{tabular}{|c|c|c|c|c|c|c|c|c|}
\hline & \multicolumn{3}{|c|}{$\begin{array}{c}\text { "Normal" Women } \\
\text { Delivering at } \\
37-38 \text { Weeks' } \\
\text { Gestation } \\
\end{array}$} & \multicolumn{3}{|c|}{$\begin{array}{l}\text { Pre-eclamptic } \\
\text { Women Delivering } \\
\text { at } 37-38 \text { Weeks' } \\
\text { Gestation }\end{array}$} & \multirow{3}{*}{$\begin{array}{l}\text { Differ- } \\
\text { ence in } \\
\text { Percen-. } \\
\text { tages }\end{array}$} & \multirow{3}{*}{$\begin{array}{l}\text { S.E. } \\
\text { of } \\
\text { Differ- } \\
\text { ence }\end{array}$} \\
\hline & \multirow{2}{*}{$\begin{array}{l}\text { No. } \\
\text { Tested }\end{array}$} & \multicolumn{2}{|c|}{ Growing } & \multirow{2}{*}{$\begin{array}{c}\text { No. } \\
\text { Tested }\end{array}$} & \multicolumn{2}{|c|}{ Growing } & & \\
\hline & & No. & $\%$ & & No. & $\%$ & & \\
\hline $\begin{array}{l}\text { Vaginal delivery } \\
\text { Caesarean section }\end{array}$ & $\begin{array}{l}15 \\
30\end{array}$ & 25 & $\begin{array}{l}60 \\
83 \cdot 3\end{array}$ & 8 & $\begin{array}{l}6 \\
8\end{array}$ & $\begin{array}{c}85 \cdot 7 \\
100\end{array}$ & $\begin{array}{l}25 \cdot 7 \\
16 \cdot 7\end{array}$ & $\begin{array}{l}18 \cdot 3 \\
7 \cdot 664\end{array}$ \\
\hline Total & 45 & 34 & $75 \cdot 5$ & 15 & 14 & 93.3 & $17 \cdot 8$ & 9.099 \\
\hline
\end{tabular}

\section{Conclusion}

In conclusion, this study is of value to virologists using amnion tissue culture in their work, since it points to means of improving culture results but going considerably beyond Duncan and Bell's speculations. From the clinical point of view, the scale of this study is too limited to permit any firm conclusions to be drawn, but seems to us to merit further, confirmatory work. The most interesting observations emerging at this stage are: (1) Although amnion is a foetal tissue, its behaviour in tissue culture is unrelated to intrauterine foetal growth and development. (2) The viability of amnion in culture declines as pregnancy progresses, but, independent of length of gestation, appears to be influenced by as yet unidentified biological changes mediating the onset of labour. Substantiation of this observation may lead to the elucidation of the nature of these changes.

\section{Summary}

Clinical data pertaining to mother and baby are correlated with the growth of human amnion in tissue culture.

Behaviour of amnion in culture is not related to intrauterine foetal growth and development.

It is shown that viability of amnion in culture declines as pregnancy progresses, but especially after the occurrence of labour, irrespective of its duration, and whatever the length of gestation.

Amnion from cases of pre-eclampsia has an enhanced success rate in tissue culture.

While the scale of this study precludes firm conclusions, it provides evidence that human amnion is sensitive to certain biological processes operative in pregnancy. If this can be confirmed some light may be shed on the actual nature of such processes.

The findings of this study are of interest to virologists using human amnion and anxious to improve the success rate of their tissue cultures.

We thank the consultant staff of Liverpool Maternity Hospital for access to women under their care, and are greatly indebted to Miss E. M. Davies, Superintendent of the Labour Ward, and her staff for their unfailing help, which made this study possible. Grateful acknowledgment is made of the help and advice given by Professor T. N. A. Jeffcoate and Professor P. E. Polani. We are also indebted to Mr. M. C. K. Tweedie and Mr. M. W. Birch for advice on the statistical treatment of the data, and to Mrs. Joan Morris and Mrs. Sylvia Lush for technical assistance.

\section{REFERENCES}

Birch, M. W. (1964). F. roy, statist. Soc. B, 26, 322.

Bourne, G. L. (1962a). The Human Amnion and Chorion, p. 117. Lloyd-Luke, London.

(1962b). Ibid., p. 185.

Duncan, I. B. R., and Bell, Eleanor, J. (1961). Brit. med. F., 2, 863.

Ferguson, J., and Tobin, J. O'H. (1958). Ibid., 1, 144.

Lahelle, O. (1956). Acta path. microbiol. scand., 39, 338.

Zitcer, E. M., Fogh, J., and Dunnebacke, T. H. (1955). Science, 122, 30 .

\title{
Herpes Simplex Lesions of Face Treated with Idoxuridine Applied by Spray Gun: Results of a Double-blind Controlled Trial
}

\author{
B. E. JUEL-JENSEN,* M.A., B.M., CAND.MED.; F. O. MACCALLUM, † M.A., M.D., B.SC., M.R.C.P.
}

Brit. med. F., 1965, 1, 901-903

In a double-blind controlled trial using $0.5 \%$ idoxuridine (I.D.U.) and placebo ointment (Juel-Jensen and MacCallum, 1964), we were unable to show any therapeutic advantage from the use of the active cream when applied to herpetic lesions of the skin. Burnett and Katz (1963) had reached similar conclusions. We suggested that this might be due to failure to get an adequate amount of the relatively insoluble substance into the affected cells, in vivo, although I.D.U. is active against herpes in vitro and in rabbit cornea. It occurred to us that it might be possible to get enough solution into close contact with the intracellular virus by spraying a fine mist of the I.D.U. solution into the skin under pressure. With a modified airgun for intradermal injections $0.1 \%$ I.D.U. solution was applied to five patients with herpes of the face. A marked

\footnotetext{
* Hospital Medical Officer, Radcliffe Infirmary, Oxford; M.O., Univer-

t Consultant Virologist, Radcliffe Infirmary, Oxford ; University Lecturer
}

clinical improvement and an apparent shortening of the duration of the lesion occurred. As the apparent advantage might be due to a purely mechanical effect, we have carried out a double-blind controlled trial to compare the effect of $0.1 \%$ solution of I.D.U. in saline with that of normal saline.

\section{Methods}

Airgun for Intradermal Injection.-A " Mark 2 " Dermojet gun was used throughout. The gun consists of a detachable nozzle, and a glass reservoir which can be removed from the main instrument by unscrewing the head. The fluid to be injected is filled into the glass reservoir after the dismantled instrument has been sterilized by boiling or autoclaving. The reservoir is pushed home and the head screwed securely on to the main instrument. A lever on the side of the barrel com- 